\title{
Clostridioides difficile infection: a comprehensive review for primary providers
}

\author{
PEDRO CORTÉS ${ }^{1}$, YAN BI ${ }^{2}$, FERNANDO STANCAMPIANO ${ }^{1}$, JOSE R. VALERY ${ }^{1}$, JANE H. COOPER ${ }^{1}$, DANA M. HARRIS ${ }^{1}$
}

\author{
${ }^{1}$ Division of Community Internal Medicine, Mayo Clinic, Jacksonville, FL, 32224 \\ ${ }^{2}$ Division of Gastroenterology and Hepatology, Mayo Clinic, Jacksonville, FL, 32224
}

\begin{abstract}
Clostridioides difficile infection (CDI) is an issue of great concern due to its rising incidence, recurrence, morbidity and impact on healthcare spending. Treatment guidelines have changed in the last few years, and new therapies are being considered. This is a practical review for the primary care practitioner of the latest guidelines for CDI diagnosis, treatment, and emerging therapies.
\end{abstract}

Key words: Clostridioides difficile, eradication, recurrent infection, fecal microbiota transplantation.

\begin{tabular}{|l|}
\hline \multicolumn{1}{|c|}{ Abbreviations: } \\
CD: Clostridioides Difficile, C. difficile; CDI: Clostridioides Difficile infection ; CDI: recurrent \\
Clostridioides Difficile infection ; FMT: Fecal microbiota transplantation ; GDH: Glutamate \\
dehydrogenase; NAAT: Nucleic acid amplification test.
\end{tabular}

\section{INTRODUCTION}

Clostridioides difficile (CD) was discovered in 1978 and identified as the main etiology of antibiotic-associated pseudomembranous colitis [1]; it was known as Clostridium difficile until 2016 when it was reclassified based on molecular information as Clostridioides difficile [2]. $\mathrm{CD}$ is a gram-positive, toxinproducing anaerobic bacterium, that causes an estimated $\$ 4.8$ billion in healthcare expenditure in the United States [3]. Approximately 453,000 cases of CDI are diagnosed each year in the United States, with 83,000 being recurrences and 29,300 resulting in death [3]. Prevalence of CDI increased in the United States and Europe from 2003 to 2006 as a result of the NAP1/BI/027 hypervirulent strain that spreads more rapidly and causes more severe illness [3,4]. However, between 2011 and 2017, the incidence of CDI has declined from 154.9 to 143.6 per 100,000 persons [5]; this in-hospital decline has been primarily driven by reductions of nosocomial infections and application of antibiotic stewardship, while community-acquired infections have remained steady [5]. Recurrent CDI (rCDI), defined by recurrence of diarrhea within two to eight weeks following successful treatment of initial CDI, remained unchanged [5]. Notably, up to $25 \%$ of patients experience rCDI within 30 days of initial treatment [6].

Antibiotic usage is the most critical risk factor for acquisition of CDI [7-9] but advanced age, hospitalization, and severe comorbid illness play a role as well [9]. Additional risk factors include enteral feeding [10], inflammatory bowel disease [11], cirrhosis [12] and gastric acid suppression [9]. Risk factors for rCDI include age older than 65 years [13-14], severe comorbidities [13-14], use of antibiotics during treatment of CDI [13-14], serum creatinine $\geq 1.2 \mathrm{mg} / \mathrm{dL}$ [13-14] and lack of antibody-mediated immune response to toxin B [15-16]. Risk factors for severe complications, such as death, admission to the ICU, toxic megacolon, perforation or colectomy, include older age, leukopenia with white blood cell (WBC) count $<4 \times 10^{9} / \mathrm{L}$ or leukocytosis with $\geq 20 \times 10^{9} / \mathrm{L}$, decreased albumin $<2.5 \mathrm{~g} / \mathrm{dL}$, elevated blood urea nitrogen > $19.6 \mathrm{mg} / \mathrm{dL}$, increased inflammatory marker $\mathrm{C}$-reactive protein $\geq 150$ $\mathrm{mg} / \mathrm{L}$, heart rate $>90 /$ minute, and respiratory rate > 20/minute [17]. Most importantly, CDI may also occur in the absence of any apparent risk factor [18]. 


\section{Whom/How to test}

1. Patients with acute diarrhea, defined as $\geq 3$ loose stools, should be tested if there is no other clear etiology [6, 19-21].

2. Two-step testing for the presence of toxin and organism should be performed, and includes [6]:

a. Stool glutamate dehydrogenase (GDH) enzyme immune assay (EIA) and toxin testing

b. GDH EIA and toxin, to be determined by nucleic acid amplification testing (NAAT) when the test result is inconclusive

c. NAAT plus toxin testing

3. Avoid re-testing within the first 7 days of therapy [6].

4. Testing asymptomatic patients is not recommended [6].

5. Do not test to document cure in patients who have completed treatment and are asymptomatic, as more than $60 \%$ of cases remain CD positive despite resolution of diarrhea [22].

\section{How to prevent transmission from patients with CDI}

1. Provide for patients a private room and toilet, if possible [6,19-21].

2. Use contact precautions consisting of gloves and gowns during encounters [6, 19-21].

3. Implement contact precautions pending diagnosis confirmation [6, 19-21].

4. Continue isolation precautions for 48 hours after diarrhea has resolved [6].

5. Wash hands with soap and water after taking off gloves in order to remove spores [23].
Alcohol-based hand sanitizers are not recommended because they are not effective $C$ difficile sporicides, although they are effective in killing the CD non-spore forms [24].

6 . Evidence to place asymptomatic patients on contact precautions remains inconclusive [6].

7. There is insufficient evidence to discontinue proton pump inhibitors to decrease CDI incidence [6].

\section{How to treat initial CDI}

Management of CDI relies on assessing disease severity to determine treatment $[6,19-21]$. CDI is categorized as mild/moderate (non-severe), severe, and fulminant. There are several schemas to determine disease severity and treatment, including guidelines from the American College of Gastroenterology (ACG) [19], the Infectious Diseases Society of America (IDSA) [6] and the European Society of Clinical Microbiology and Infectious Diseases (ESCMID) [20-21]. Table 1. The IDSA updated its treatment recommendations in 2017 given new evidence of vancomycin being superior to metronidazole for preventing rCDI, and fidaxomicin being as efficacious as vancomycin for treating $\mathrm{CDI}$ and superior for preventing rCDI [6]. The guidelines removed metronidazole as treatment of mild or moderate disease and included fidaxomicin as treatment of mild, moderate, and severe CDI and for the treatment of rCDI. Guidelines from ACG and ESCMID are older and still recommend metronidazole for mild or moderate disease; ESCMID recommends fidaxomicin for rCDI

Table 1

Classification of CDI Severity from 2017 IDSA and 2014 ESCMID $^{1}$

\begin{tabular}{|c|c|c|}
\hline \multicolumn{3}{|c|}{ Classification of CDI Severity } \\
\hline & 2017 IDSA Classification & 2014 ESCMID Classification [37] \\
\hline Non-severe & $\begin{array}{ll}- & \mathrm{WBC}<15 \times 10^{9} / \mathrm{L} \\
- & \text { Creatinine }<1.5 \mathrm{mg} / \mathrm{dL}\end{array}$ & $\begin{array}{l}\text { - } \quad \text { Stool frequency }<4 \text { times daily } \\
\text { - } \quad \text { No signs of severe colitis }\end{array}$ \\
\hline Severe & $\begin{array}{ll}\text { - } & \mathrm{WBC}>15 \times 10^{9} / \mathrm{L} \\
\text { - } & \text { Creatinine }>1.5 \mathrm{mg} / \mathrm{dL}\end{array}$ & $\begin{array}{ll}\text { - } & \text { Severe colitis OR } \\
\text { - } & \text { Complicated course with shock }\end{array}$ \\
\hline Fulminant & $\begin{array}{ll}\bullet & \text { Hypotension } \\
\bullet & \text { Ileus } \\
\bullet & \text { Megacolon }\end{array}$ & $\begin{array}{ll}- & \text { Need for ICU admission } \\
- & \text { WBC }>15 \times 10^{9} / \mathrm{L} \\
- & \text { Albumin }<3 \mathrm{~g} / \mathrm{dL} \\
\text { - } & \begin{array}{l}\text { Creatinine }>1.3 \mathrm{mg} / \mathrm{dL} \text { or } 1.5 \text { times above } \\
\text { baseline }\end{array}\end{array}$ \\
\hline
\end{tabular}

WBC: White Blood Cells

ICU: Intensive Care Unit

${ }^{1} 2014$ ESCMID classification of non-severe and severe 
Because CDI is a dysbiosis, the most important aspect of treatment and prevention of recurrence is the discontinuation of the inciting antibiotic(s) in addition to providing supportive care [6].
Replenishing the microbiota is also the rationale behind the successful treatment of FMT. IDSA recommendations for treating a first episode of CDI are summarized in Table 2.

\section{Table 2}

Treatment of initial episode of CDI

\begin{tabular}{|c|c|c|}
\hline \multicolumn{3}{|c|}{ Treatment of initial episode of Clostridium difficile infection } \\
\hline Classification & Recommended Treatment & $\begin{array}{l}\text { Strength of Recommendation/ } \\
\text { Quality of Evidence }\end{array}$ \\
\hline \multirow[t]{3}{*}{ Non-severe } & PO VAN 125 mg QID for $10-14 d$, or & \multirow{3}{*}{$\begin{array}{l}\text { Strong/High } \\
\text { Strong/High } \\
\text { Weak/High }\end{array}$} \\
\hline & PO FDX $200 \mathrm{mg}$ BID for 10d, or & \\
\hline & PO MTZ 500mg TID for 10 or $14 \mathrm{~d}$ & \\
\hline \multirow[t]{2}{*}{ Severe } & PO VAN 125 mg QID for 10d, or & \multirow{2}{*}{$\begin{array}{l}\text { Strong/High } \\
\text { Strong/High }\end{array}$} \\
\hline & PO FDX 200 mg BID for 10d & \\
\hline \multirow[t]{3}{*}{ Fulminant } & PO VAN 500 mg QID, or & \multirow{3}{*}{$\begin{array}{l}\text { Strong/Moderate } \\
\text { Weak/Low } \\
\text { Strong/Moderate }\end{array}$} \\
\hline & PR VAN 500 mg/100 mL NS enema Q6H & \\
\hline & and IV MTZ $500 \mathrm{mg}$ Q8H with VAN & \\
\hline
\end{tabular}

VAN: Vancomycin

FDX: Fidaxomicin

MTZ: Metronidazole

QID: four times daily

BID: twice daily

TID: three times daily

NS: normal saline
1. For non-severe cases, one of the following regimens may be used:

- PO Vancomycin $125 \mathrm{mg}$ four times daily for 10 days OR

- PO Fidaxomicin $200 \mathrm{mg}$ twice daily for 10 days OR

- PO Metronidazole $500 \mathrm{mg}$ three times daily for 14 days, if vancomycin or fidaxomicin are not available

2. For severe cases, treatment with oral vancomycin or oral fidaxomicin, as above, is recommended. Metronidazole should be avoided for severe CDI.

3. For fulminant cases, the following regimen is recommended:

- PO Vancomycin $500 \mathrm{mg}$ four times daily OR

- PR retention enema Vancomycin $500 \mathrm{mg}$ in $100 \mathrm{~mL}$ normal saline every 6 hours if ileus is present
AND

- IV Metronidazole $500 \mathrm{mg}$ every 8 hours concurrently

4. For surgical management of acute abdomen, megacolon, colonic perforation, or septic shock with organ failure, a subtotal colectomy with rectum preservation is preferred. An alternative approach for colonic preservation is a diverting loop ileostomy with colonic lavage followed by antegrade vancomycin flushes [6].

- Early surgical intervention may be indicated in selected patients with a rising WBC count $\left(\geq 25 \times 10^{9} / \mathrm{L}\right)$ or lactate $(\geq 5 \mathrm{mmol} / \mathrm{L})[6]$.

\section{How to treat rCDI}

The number of recurrences of CDI and the regimen used for the initial episode of CDI determine the treatment for rCDI [6]. Recommendations for rCDI are summarized in Table 3. 
1. For an initial recurrence of CDI, the following regimens may be used:

- PO Vancomycin $125 \mathrm{mg}$ four times daily for 10 to 14 days if metronidazole was initially used, OR

- Vancomycin taper, as shown below:

- PO vancomycin $125 \mathrm{mg}$ four times daily for 10 days, followed by
○ PO vancomycin $125 \mathrm{mg}$ twice daily for 7 days, followed by

- PO vancomycin $125 \mathrm{mg}$ once daily for 7 days, followed by

- PO vancomycin $125 \mathrm{mg}$ every 2 or 3 days for 2-8 weeks

Alternatively, PO Fidaxomicin $200 \mathrm{mg}$ twice daily for 10 days may be used

Table 3

Treatment of recurrent episode of CDI

\begin{tabular}{|c|c|c|}
\hline \multicolumn{3}{|c|}{ Treatment of recurrent episodes of Clostridium difficile infection } \\
\hline Classification & Recommended Treatment & $\begin{array}{l}\text { Strength of Recommendation/ } \\
\text { Quality of Evidence }\end{array}$ \\
\hline \multirow[t]{3}{*}{ Initial recurrence } & PO VAN 125 mg QID for 10 days*, or & Weak/Low \\
\hline & $\begin{array}{l}\text { PO VAN } 125 \mathrm{mg} \text { QID for } 10-14 \mathrm{~d} \text {, then } \\
\text { PO VAN } 125 \mathrm{mg} \text { BID for 7d, then } \\
\text { PO VAN } 125 \mathrm{mg} \text { QD for } 7 \mathrm{~d} \text {, then } \\
\text { PO VAN } 125 \mathrm{mg} \text { Q2-3d for } 2-8 \mathrm{w} \text {, or }\end{array}$ & Weak/Low \\
\hline & PO FDX $200 \mathrm{mg}$ BID for $10 \mathrm{~d} \dagger$ & Weak/Moderate \\
\hline \multirow[t]{4}{*}{ Second recurrence } & Repeat taper and pulse VAN as above & Weak/Low \\
\hline & $\begin{array}{l}\text { PO VAN } 125 \text { mg QID for 10d, then } \\
\text { PO RFX } 400 \text { mg TID for } 20 \mathrm{~d} \text {, or }\end{array}$ & Weak/Low \\
\hline & PO FDX 200 mg BID for 10d, or & Weak/Low \\
\hline & FMT & Strong/Moderate \\
\hline
\end{tabular}

* if MTZ was used for initial episode of CDI

$\dagger$ if VAN was used for initial episode of CDI

$\$$ appropriate if at least 2 recurrences (i.e., 3 total episodes of CDI)

RFX: Rifaximin

2. For subsequent recurrences of CDI, the following regimens are recommended:

- Repeating vancomycin taper as above, OR

- PO Vancomycin $125 \mathrm{mg}$ four times daily for 10 days, followed by PO Rifaximin $400 \mathrm{mg}$ three times daily for 20 days, OR

- PO Fidaxomicin $200 \mathrm{mg}$ twice daily for 10 days, OR

- Fecal microbiota transplantation (FMT) is recommended for patients with at least 2 recurrent episodes of CDI

- Indications for FMT include [25]

1) recurrent or relapsing $\mathrm{CDI}$

2) $\geq 3$ episodes of mild-to-moderate CDI
3) $\geq 2$ episodes of severe CDI

- FMT is not recommended in the following [25]

1) severe food-related allergic reactions

2) pregnancy or ongoing lactation

3) contraindications to colonoscopy or nasogastric insertion

4) immunodeficiency (compensated cirrhosis, uncontrolled HIV, bone marrow transplant within 6 weeks)

5) therapy with immunosuppressant agents (chemotherapy, calcineurin inhibitors, corticosteroids)

How to treat pediatric patients

1. Testing asymptomatic infants $<1$ year of age is never recommended given the high prevalence of carriers [6] 
2. Test children 2 years or older if they develop worsening or protracted diarrhea with risk factors, including inflammatory or immunocompromising conditions [6]

3. Recommendations for contact precautions and hand washing are the same as for adults [6]

4. Treatment is determined by diseases severity as previously described [6]

- Treat non-severe cases of initial CDI with

○ PO Metronidazole for 10 days at $7.5 \mathrm{mg} / \mathrm{kg} /$ dose three to four times daily

- Do not exceed $500 \mathrm{mg}$ three times or four times daily

- PO Vancomycin for 10 days at $10 \mathrm{mg} / \mathrm{kg} / \mathrm{dose}$ four times daily

- Do not exceed $125 \mathrm{mg}$ four times daily

- Treat severe or fulminant cases of initial CDI with

- PO/PR Vancomycin as above with or without IV Metronidazole at $10 \mathrm{mg} / \mathrm{kg} /$ dose three times daily

- Do not exceed $500 \mathrm{mg}$ three times daily of Metronidazole

- Add IV Metronidazole if patient is critically ill

5. Treat a first recurrence as described above with

PO Metronidazole for 10 days or PO Vancomycin for

10 days [6]

6. Treat subsequent recurrences with [6]

- Vancomycin taper, as shown below:

- PO Vancomycin $10 \mathrm{mg} / \mathrm{kg}$ [max $125 \mathrm{mg}$ ] four times daily for 10-14 days, followed by

- PO Vancomycin $10 \mathrm{mg} / \mathrm{kg}$ [max $125 \mathrm{mg}$ ] two times daily for 7 days, followed by

- PO Vancomycin $10 \mathrm{mg} / \mathrm{kg}$ [max $125 \mathrm{mg}$ ] once daily for 7 days, followed by

- PO Vancomycin $10 \mathrm{mg} / \mathrm{kg}$ [max $125 \mathrm{mg}$ ] every 2 or 3 days for $2-8$ weeks

- $\mathrm{PO}$ Vancomycin for 10 days at $10 \mathrm{mg} / \mathrm{kg} / \mathrm{dose}$ four times daily, followed by PO Rifaximin for 20 days

- Do not exceed $125 \mathrm{mg}$ four times daily of Vancomycin

- Rifaximin is not approved by the FDA in children less than 12 years old

- There is no pediatric dosing for Rifaximin. Do not exceed $400 \mathrm{mg}$ three times daily of Rifaximin.

FMT is indicated if patients have at least 3 episodes of CDI

\section{What new treatments are underway}

CDI disruption of gut microbiota resulting in decreased bacterial diversity and proliferation of toxic species increases the risk of treatment failure and recurrence of infection. Emerging therapies for the treatment and prevention of rCDI involve orally replacing spores from healthy donors, microbiotabased formulations, introducing non-toxigenic C. difficile in the colon, using monoclonal antibodies, narrow spectrum antibiotics and probiotics. Also, importance is being given to prophylactic oral vancomycin to prevent CDI. Studies of vaccines are limited.

Seres Therapeutics, Inc product SER-109 is a capsule containing CD spores from healthy individuals that may decrease rCDI [26]. Several companies are investigating the effects of oral capsule formulations of microbiota (CP101 by Finch Therapeutics, RBX7455 by Rebiotics, Inc, SER-262 by Seres Therapeutics, Inc) and Rebiotix, Inc is studying a microbiota formulation delivered via enema (RBX2660) that shows superiority over placebo at preventing rCDI (79\% vs 52\%) and faster gut flora recovery compared to the discontinuation of antibiotic alone [27]. In a 2015 placebo-controlled Phase II trial, patients treated successfully for CDI were enrolled. Those that took a nontoxigenic C. difficile strain $\mathrm{M} 3$ orally had lower rCDI compared to placebo (2\% vs $31 \%$ ) [28].

Antibody-based treatments have shown promise in treating CDI. Bezlotoxumab is an FDA-approved monoclonal antibody that binds to toxin $\mathrm{B}$ and is used in conjunction with $\mathrm{CDI}$ antibacterial treatment to prevent $\mathrm{rCDI}$ in patients at high risk for recurrence [29]. Two Phase 3 randomized, double-blind, placecontrolled trials (MODIFY I and MODIFY II), showed bezlotoxumab reduced rates of rCDI regardless of the treatment choice of first CDI episode [30]. The number needed to treat to prevent one episode of rCDI was 9 and 10, respectively, with the drug being most cost-effective in patients with the highest number of risk factors [31].

Ridinilazole is a non-absorbable narrow-spectrum antibiotic that may affect cell division of $C$. difficile without disrupting other microbiota. A recent Phase 2 trial of ridinilazole compared to vancomycin showed a greater sustained response in preventing rCDI $(66.7 \%$ vs $42.4 \%)$ [32]; a phase 3 trial of ridinilazole is currently underway.

There is limited evidence that prophylactic oral vancomycin prevents rCDI, but patients at high risk for recurrence such as the immunocompromised or those on systemic antibiotics may benefit from it $[29,33]$.

Increasing specific immunity against $\mathrm{CD}$ in vaccine experimental models has been shown effective in decreasing the number of CD stool cells and increasing survival [34-34]. 


\section{Strategy to be used in primary care clinics}

- Suspect CDI in patients with multiple episodes of diarrhea without a clear etiology.

- Consider testing for CDI and use a two-step approach.

- Initiate contact precautions while waiting for test results.

- Treat with oral vancomycin or fidaxomicin for 10 days for an initial episode of non-severe or severe CDI.
- Recommend hospitalization for patients with severe or fulminant CDI. For fulminant CDI, add intravenous metronidazole to the oral high-dose vancomycin regimen, and if no improvement, evaluate the patient for surgery.

- Treat rCDI with a prolonged taper and pulse regimen of vancomycin or fidaxomicin. FMT should be considered in patients with at least 2 recurrent episodes of CDI who are not immunocompromised.

- Testing for cure is not recommended.

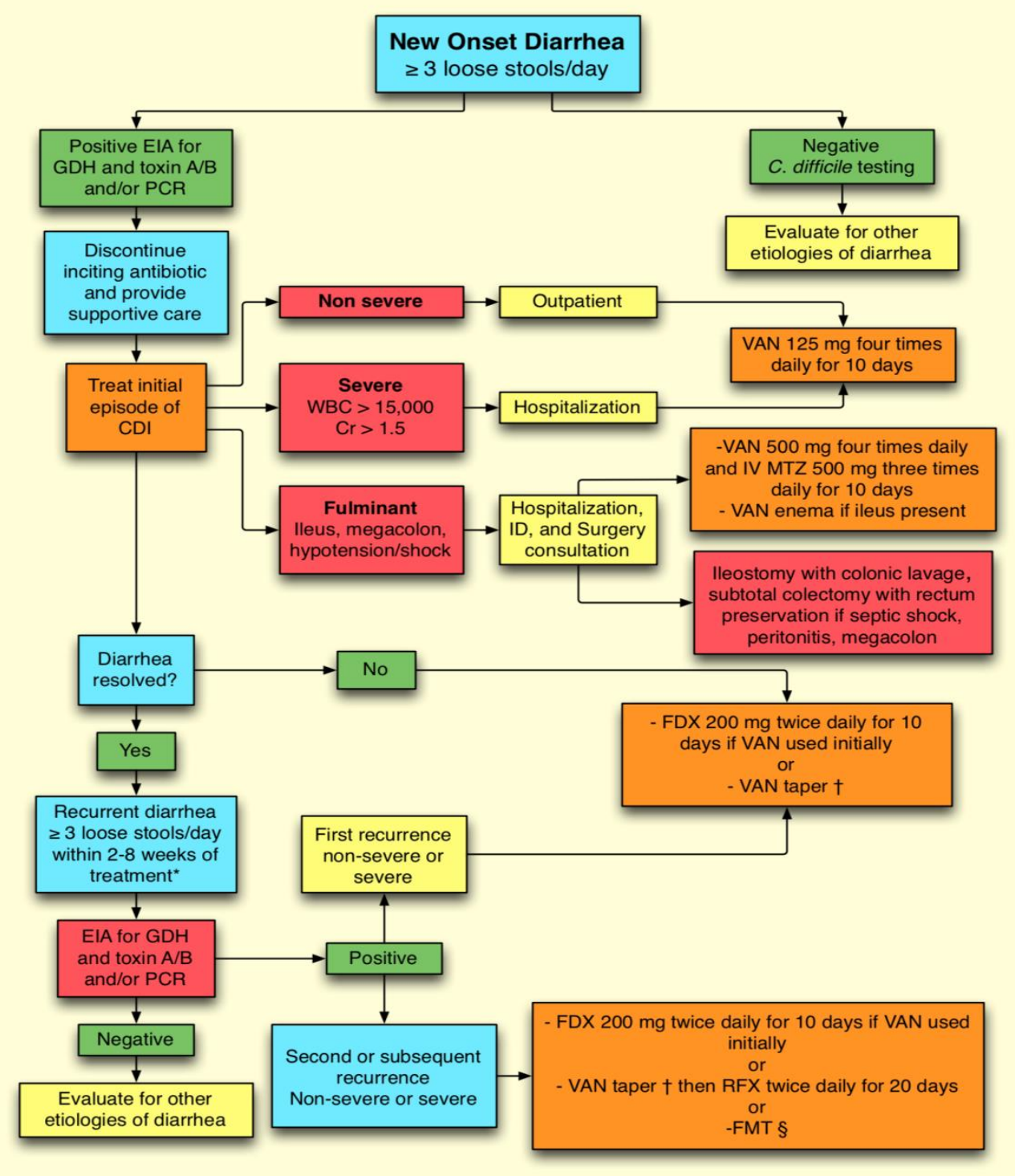

Figure 1. Management of Clostridioides difficile infection.

GDH: Glutamate dehydrogenase

CDI: Clostridioides difficile infection

VAN: Vancomycin

FMT: Fecal Microbiota TransplantationRFX: Rifaximin

ID: infectious diseases
EIA: Enzyme immunoassay

rCDI: recurrent CDI

FDX: Fidaxomicin 
* $20 \%$ of patients fail initial CDI therapy; 40-60\% will have a second recurrence [36];

$25 \%$ of patients treated successfully for initial CDI will experience recurrence within 30 days [6]

$\dagger$ VAN taper: PO vancomycin $125 \mathrm{mg}$ four times daily for 10-14 days, followed by PO vancomycin 125 mg twice daily for 7 days, followed by PO vancomycin $125 \mathrm{mg}$ once daily for 7 days, followed by PO vancomycin $125 \mathrm{mg}$ every 2 or 3 days for 2-8 weeks

$\S$ Indications for FMT include 1) recurrent/relapsing CDI, 2) $\geq 3$ episodes of mild-to-moderate CDI with failure of tapering

vancomycin, 3$) \geq 2$ episodes of severe CDI

\section{CONCLUSION}

Primary care providers are essential in detecting and managing patients with CDI. We believe this concise review will facilitate understanding of the disease and lead to improved patient care.

Infecția cu Clostridium difficile este o problemă ce provoacă mare îngrijorare din cauza incidenței sale în creștere, a recurenței, a morbidității și a impactului asupra cheltuielilor associate ingrijirilor de sănătate. Ghidurile de tratament au fost modificate în ultimii ani și noi terapii sunt luate în considerare. Aceasta este o trecere în revistă practică a literaturii de specialitate dedicate medicului de familie și conține ultimele recomandări pentru diagnosticul și tratamentul infecției cu $C$. difficile, precum și noile terapii emergente.

Correspondence to: Dana Harris, MD, Mayo Clinic Jacksonville, FL 32224., Tel: +1 904-953-9543, Fax: +1 904-953-0655, Email: Harris.Dana@mayo.edu

Conflict of interest desclosure: The authors declare no conflicts of interest.

\section{REFERENCES}

1. BARTLETT JG. Narrative review: the new epidemic of Clostridium difficile-associated enteric disease. Ann Intern Med. 2006;145(10):758-64.

2. LAWSON PA., CITRON DM., TYRRELL KL., FINEGOLD SM. Reclassification of Clostridium difficile as Clostridioides difficile (Hall and O'Toole 1935) Prévot 1938. Anaerobe. 2016;40:95-9.

3. LESSA FC., WINSTON LG., MCDONALD LC. Emerging Infections Program CdST. Burden of Clostridium difficile infection in the United States. N Engl J Med. 2015;372(24):2369-2370.

4. MILLER M., GRAVEL D., MULVEY M., TAYLOR G., BOYD D., SIMOR A., et al. Health care-associated Clostridium difficile infection in Canada: patient age and infecting strain type are highly predictive of severe outcome and mortality. Clin Infect Dis. 2010;50(2):194-201.

5. GUH AY., MU Y., WINSTON LG., JOHNSTON H., OLSON D., FARLEY MM., et al. Trends in U.S. Burden of Clostridioides difficile Infection and Outcomes. N Engl J Med. 2020;382(14):1320-1330.

6. MCDONALD LC., GERDING DN., JOHNSON S., BAKKEN JS., CARROLL KC., COFFIN SE., et al. Clinical Practice Guidelines for Clostridium difficile Infection in Adults and Children: 2017 Update by the Infectious Diseases Society of America (IDSA) and Society for Healthcare Epidemiology of America (SHEA) Clin Inf Diseases. 2018;66(7):e1-e48.

7. THOMAS C., STEVENSON M., RILEY TV. Antibiotics and hospital-acquired Clostridium difficile-associated diarrhoea: a systematic review. J Antimicrob Chemother. 2003;51(6):1339-50.

8. WISTROM J., NORRBY SR., MYHRE EB., ERIKSSON S., GRANSTROM G., LAGERGREN., et al. Frequency of antibioticassociated diarrhoea in 2462 antibiotic-treated hospitalized patients: a prospective study. J Antimicrob Chemother. 2001;47(1):43-50.

9. LOO VG., BOURGAUALT AM., POIRIER L., LAMOTHE F., MICHAUD S., TURGEON N., et al. Host and pathogen factors for Clostridium difficile infection and colonization. N Engl J Med. 2011;365(18):1693-703.

10. BLISS DZ., JOHNSON S., SAVIK K., CLABOTS CR., WILLARD K., GERDING DN., et al. Acquisition of Clostridium difficile and Clostridium difficile-associated diarrhea in hospitalized patients receiving tube feedings. Ann Intern Med. 1998;129(12):1012-9.

11. SINGH H., NUGENT Z., YU BN., LIX LM., TARGOWNIK LE., BERNSTEIN CN., et al. Higher Incidence of Clostridium difficile Infection Among Individuals With Inflammatory Bowel Disease. Gastroenterology. 2017;153(2):430-438.

12. REIGADAS E., ALCALA L., GOMEZ J., MARIN M., MARTIN A., ONORI R., et al. Breakthrough Clostridium difficile Infection in Cirrhotic Patients Receiving Rifaximin. Clin Infect Dis. 2018;66(7):1086-1091.

13. HU MY., KATCHAR K., KYNE L., MAROO S., TUMMALA S., DREISBACH V., et al. Prospective derivation and validation of a clinical prediction rule for recurrent Clostridium difficile infection. Gastroenterology. 2009;136(4):1206-14. 
14. D’AGOSTINO RB SR., COLLINS SH., PENCINA KM., KEAN Y., GORBACH S. Risk estimation for recurrent Clostridium difficile infection based on clinical factors. Clin Infect Dis. 2014;58(10);1386-93.

15. KYNE L., WARNY M., QAMAR A., KELLY CP. Association between antibody response to toxin A and protection against recurrent Clostridium difficile diarrhoea. Lancet. 2001;357(9251):189-93.

16. GUPTA SB., MEHTA V., DUBBERKE ER., ZHAO X., DORR MB., GURIS D., et al. Antibodies to Toxin B Are Protective Against Clostridium difficile Infection Recurrence. Clin Infec Dis. 2016;63(6):730-734.

17. ABOU CHAKRA CN., MCGEER A., LABBE AC., SIMOR AE., GOLD WL., MULLER MP., et al. Factors Associated With Complications of Clostridium difficile Infection in a Multicenter Prospective Cohort. Clin Infect Dis. 2015;61(12):1781-8.

18. ABRAHAM FM., TALAN DA., KRISHNADASAN A., CITRON DM., PAULICK AL., ANDERSON LJ., et al. Clostridium difficile Infection Among US Emergency Department With Diarrhea and No Vomiting. Ann Emerg Med. 2017;70(1):19-27.

19. SURAWICZ CM., BRANDT LJ., BINION DG., ANANTHAKRISHNAN AN., CURRY SR., GILLIGAN PH., et al. Guidelines for diagnosis, treatment, and prevention of Clostridium difficile infections. Am J Gastroenterol. 2013;108(4):478-98.

20. BAUER MP., KUIJPER EJ., VAN DISSEL JT. European Society of Clinical Microbiology and Infectious Diseases (ESCMID): treatment guidance document for Clostridium difficile infection (CDI). Clin Microbiol Infect. 2009;15(12):1067-79.

21. DEBAST SB., BAUER MP., KUIJPER EJ. European Society of Clinical Microbiology and Infectious Diseases: update of the treatment guidance document for Clostridium difficile infection. Clin Microbiol Infect. 2014;20 Supple 2:1-26.

22. ABUJAMEL T., CADNUM JL., JURY LA., SUNKESULA VC., KUNDRAPU S., JUMP RL., et al. Defining the vulnerable period of re-establishment of Clostridium-difficile colonization after treatment of $C$. difficile infection with oral vancomycin or metronidazole. PLoS One. 2013;8(10):e76269.

23. DOLL M., MARRA AR., APISARNTHANARAK A., AL-MAANI AS., ABBAS S., ROSENTHAL VD. Prevention of Clostridioides difficile in hospitals: A position paper of the International Society for Infectious Diseases. Int J Infect Dis. 2021;102;188-195.

24. FORRESTER JD., BANAEI N., BUCHNER P., SPAIN DA., STAUDENMAYER KL. Environmental Sampling for Clostridium Difficile on Alcohol-Based Hand Rub Dispensers in an Academic Medical Center. Surg Infect. 2014;15(5):581-4.

25. MULLISH BH., MARCHESI JR., THURSZ MR., WILLIAMS HR. Microbiome manipulation with faecal microbiome transplantation as a therapeutic strategy in Clostridium difficile infection. QJM. 2015;108(5):355-9.

26. CHO JM., PARDI DS., KHANNA S. Update on Treatment of Clostridioides difficile Infection. Mayo Clin Proc. 2020;95(4):758-769.

27. KWAK S., CHOI J., HINK T., RESKE KA., BLOUNT K., JONES C., et al. Impact of investigational microbiota therapeutic RBX2660 on the gut microbiome and resistome revealed by a placebo-controlled clinical trial. Microbiome. 2020;8(1):125.

28. GERDING DN., MEYER T., LEE C., COHEN SH., MURTHY UK., POIRIER A., et al. Administration of spores of nontoxigenic Clostridium difficile strain M2 for prevention of recurrent $C$. difficile infection: a randomized clinical trial. JAMA. 2015;313(17):1719-27.

29. ALONSO CD., MAHONEY MV. Bezlotoxumab for the prevention of Clostridium difficile infection: a review of current and safety profile. Infect Drug Resist. 2018;12:1-9.

30. WILCOX MH., GERDING DN., POXTON IR., KELLY C., NATHAN R., BIRCH T., et al. Bezlotoxumab for Prevention of Recurrent Clostridium difficile Infection. N Engl J Med. 2017;376(4):305-317.

31. GERDING DN., KELLY CP., RAHAV G., LEE C., DUBBERKE ER., KUMAR PN., et al. Bezlotoxumab for Prevention of Recurrent Clostridium difficile Infection in Patients at Increased Risk for Recurrence. Clin Infect Dis. 2018;67(5):649-656.

32. VICKERS RJ., TILLOTSON GS., NATHAN R., HAZAN S., PULLMAN J., LUCASTI C., et al. Efficacy and safety of ridinilazole compared with vancomycin for the treatment of Clostridium difficile infection: a phase 2, randomised, double-blind, active-controlled, non-inferiority study. Lancet Infect Dis. 2017;17(7):735-744.

33. GANETSKY A., HAN JH., HUGHES ME., BABUSHOK DV., FREY NV. GILL SI., et al. Oral Vancomycin Prophylaxis Is Highly Effective in Preventing Clostridium difficile Infection in Allogeneic Hematopoietic Cell Transplant Recipients. Clin Infect Dis. 2019;68(12):2003-2009.

34. SENOH M., IWAKI M., YAMAMOTO A., KATO H. FUKUDA T. SHIBAYAMA K. Development of vaccine for Clostridium difficile infection using membrane fraction of nontoxigenic Clostridium difficile. Microb Pathog. 2018;123:42-46.

35. ZHANG C., JIN K., XIAO Y., CHENG Y., HUANG Z., WANG S., et al. Potent monoclonal antibodies against Clostridium difficile toxin A elicited by DNA immunization. Hum Vaccin Immunother. 2013;9(10):2157-64.

36. HOPKINS RJ., WILSON RB. Treatment of recurrent Clostridium diffiicle colitis: a narrative review. Gastroenterol Rep. 2018;6(1):21-28.

37. OOIJEVAAR RE., VAN VEURDEN YH., TERVEER EM., GOORHUIS A., BAUER MP., KELLER JJ., et al. Update on treatment algorithms for Clostridium difficile infection. Clin Micribiol Infect. 2018;24(5):452-462.

Received $1^{\text {st }}$ February 2021 